\section{Antiemetic prophylaxis with promethazine or droperidol in paediatric outpatient strabismus surgery}

Victor Faria Blanc MD FRCPC,

Pierre Ruest MD FRCPCl, Jean Milot MD FRCSCI, Jean-Louis Jacob MD FRCSC, Alexander Tang MD FRCPC
This randomized, double-blind study evaluated the antiemetic efficacy and the side-effects of promethazine pretreatment 10.5 $\mathrm{mg} \cdot \mathrm{kg}^{-1} \mathrm{IV}+0.5 \mathrm{mg} \cdot \mathrm{kg}^{-1}(\mathrm{M})$ versus droperidol + placebo pretreatment (droperidol, $0.075 \mathrm{mg} \cdot \mathrm{kg}^{-1} \mathrm{IV}+$ physiological saline, $0.02 \mathrm{ml} \cdot \mathrm{kg}^{-1}(\mathrm{M})$. One hundred unpremedicated ASA physical status I children ranging from two to ten years, and undergoing outpatient strabismus surgery were studied. All children received inhalational anaesthesia with halothane, nitrous oxide and oxygen. Neither opioids nor muscle relaxants were used. The incidence of vomiting andlor retching and the incidence of side-effects were determined in the postanaesthesia recovery room (PARR), in the short-stay surgical unit (SSSU), and after discharge from the hospital (including the journey and the stay at home during the first postoperative day). Promethazine and droperidol were equally effective in reducing the incidence of vomiting before discharge to two and eight per cent respectively. On the contrary, the incidences of vomiting after discharge and overall were significantly less with promethazine (ten and ten per cent) than with droperidol pretreatment (54 and 56 per cent) $(P<0.0001)$. Promethazine permitted the time to discharge from the hospital to be reduced to an average of three hours, without increasing the incidence of vomiting postdischarge. Promethazine pretreatment is much less expensive than droperidol pretreatment. The incidence of restlessness was significantly less with droperidol (eight per cent) than with

\section{Key words}

ANAESTHESIA: outpatient, paediatric;

SURGERY: ophthalmic;

vOMITING: antiemetics, droperidol, promethazine, incidence.

From the Departments of Anaesthesia and Ophthalmology, Hôpital Sainte-Justine and Université de Montréal Montréal, Québec, Canada.

Address correspondence to: Dr. V.F. Blanc, Department of Anaesthesia, Hôpital Sainte-Justine, 3175 Côte Ste-Cathcrine, Montréal, Québec, Canada, H3T 1C5 Accepted for publication 14th September, 1990. promethazine (36 percent) $(P<0.001)$. Promethazine pretreatment demands the use of an analgesic like acetaminophen in order to reduce the incidence of postoperative pain and restlessness. With the exception of restlessness, the overall incidence of side-effects was not statistically different between the two groups.

Cette étude randomisée et à double insu a été réalisée dans le but d'évaluer et l' efficacité antiémétique et les effets indésirables du prétraitement à la prométhazine $\left(0,5 \mathrm{mg} \cdot \mathrm{kg}^{-1} \mathrm{IV}+0,5\right.$ $\mathrm{mg} \cdot \mathrm{kg}^{-l}(M)$ versus le prétraitement au droperidol + placebo (droperidol, 0,075 $\mathrm{mg} \cdot \mathrm{kg}^{-1} \mathrm{I}+$ sérum physiologique, 0.02 $\mathrm{ml} \cdot \mathrm{kg}^{-1} \mathrm{IM}$ ). Cent enfants non prémédiqués, à l'état physiquel de la classification ASA, dont l'âge variait entre deux et dix ans er devan subir une correction de strabisme en court-séjour ont été étudiés. Tous ces enfants on èté anesthésiés à l'aide d'halothane, de protoxyde d'azote et d'oxygène. Aucun opiacé et aucun curarisant n'a été employé. L incidence de vomissements et l'incidence d'effets indésirables fûrent déterminées à la salle de réveil, à l'unité de court-séjour postopératoire, et après le congédiement de l'hopital (transport vers la maison er séjour à domicile pendant la première journée postopératoire). Le prétraitement à la prométhazine a réduit l'incidence de vomissements pré-congédiement de l'hôpital (deux pour cent) autant que le prétraitement au droperidol (huit pour cent). Par contre. I'incidence de vomissements post-congédiement de l'hôpital et l' incidence globale de vomissements postopératoires fûrent significativement plus faibles chez le groupe d'enfants prétraités avec de la prométhazine (dix; dix pour cent) que chez le groupe prétraité avec du droperidol (54:56 pour cent) $(P<$ $0,0001)$. Le prétraitement à la prométhazine a permis de raccourcir la moyenne du temps de congédiement de l'hôpital aux alentours de trois heures sans augmenter l'incidence de vomissements post-congédiement. Le prétrairement à la pro. méthazine coûte beaucoup moins cher que le prétraitement au droperidol. L'incidence d' agitation postopératoire fut significativement plus élevée avec la prométhazine (36 pour cent qu' avec. le droperidol (huit pour cent) $(P<0,001)$. Les enfants prétraités à la prométhazine doivent recevoir un analgésique du type acéta. 
minophène, dans le but de réduire l'incidence de douleurs et d'agitation postopératoires. Mise à part l'agitation, l'incidence globale d'effets indésirables n'a pas été statistiquement différente entre les deux types de prétraitement. Les auteurs discutent l'étiopathogénie des vomissements et la pharmacologie des antiémétiques chez les enfants exposés aux corrections de strabisme.

Children undergoing general anaesthesia for strabismus surgery have a higher incidence of postoperative vomiting than those receiving the same anaesthesia for other types of ambulatory surgical procedures. ${ }^{1-4}$ The incidence of vomiting following strabismus correction in children not receiving any antiemetic has been reported to range from 60 to 85 per cent. ${ }^{2.5 .6}$ Droperidol, $0.05 \mathrm{mg} \cdot \mathrm{kg}^{-1} \mathrm{IV}$, given at induction of anaesthesia, does not reduce the incidence of emetic symptoms (nausea, retching and vomiting) in preschool children undergoing outpatient strabismus surgery. ${ }^{5}$ The incidence of retching and/or vomiting predischarge in children who received droperidol, $0.075 \mathrm{mg} \cdot \mathrm{kg}^{-1} \mathrm{IV}$, before manipulation of the eye is less than that observed in children who received the same dose of droperidol IV after manipulation of the eye (10 and 43 per cent, respectively). ${ }^{2,6}$ The incidence of vomiting predischarge (retching not included) in children who received metoclopramide, $0.15 \mathrm{mg} \cdot \mathrm{kg}^{-1} \mathrm{IV}$ in the post-anaesthesia recovery room, is 35 per cent. ${ }^{7}$ Studies regarding the antiemetic efficacy of intravenous lidocaine (1.5-2 $\mathrm{mg} \cdot \mathrm{kg}^{-1}$ ) show both benefit and lack of benefit, the incidence of postoperative vomiting varying from $16^{8}$ to 50 per cent. ${ }^{9}$ Promethazine has a long history of usefulness in paediatric anaesthesia. In addition to its sedative properties, it has anticholinergic, antihistaminic, antiemetic, and anti-motion sickness effects. The recommended dose for children is $0.5-1.0 \mathrm{mg} \cdot \mathrm{kg}^{-1}$ of body weight. ${ }^{10-12}$ We speculated that if intravenous promethazine were administered before manipulation of the eye and combined with intramuscular promethazine, the incidence of vomiting following strabismus surgery might be reduced even more than with intravenous droperidol pretreatment. Therefore, the incidence of vomiting after strabismus correction was determined in children who received intravenous droperidol pretreatment associated with an intramuscular placebo, or intravenous promethazine pretreatment associated with intramuscular promethazine.

\section{Methods}

With approval of the hospital Committee on Medical Ethics, informed consent was obtained from the parents of 100 children ( 47 boys and 53 girls), ASA physical status $\mathrm{I}$, between two to ten years of age, and requiring outpatient strabismus surgery.
Children were fasting and unpremedicated. The following monitors were used in all children: precordial stethoscope, continuous ECG (CM-5), blood pressure measurements with an automatic cuff (Dinamap ${ }^{\mathbb{B}}$ ), pulse oxymeter (Ohmeda ${ }^{\circledR}$ ), and rectal thermometer.

Induction of anaesthesia was achieved with halothane, nitrous oxide and oxygen ( 40 per cent) by mask. An IV cannula was then inserted and connected to an infusion of five per cent dextrose and lactated Ringer's solution ( 8 $\mathrm{ml} \cdot \mathrm{kg}^{-1} \cdot$ hour ${ }^{-1}$ ). After intravenous atropine, $0.01 \mathrm{mg}$. $\mathrm{kg}^{-1}$, children were randomly assigned to one of two treatment groups: intravenous droperidol, $0.075 \mathrm{mg} \cdot \mathrm{kg}^{-1}$, plus intramuscular placebo (physiological saline, 0.02 $\mathrm{ml} \cdot \mathrm{kg}^{-1}$, to a maximum of $\left.0.5 \mathrm{ml}\right),(n=50)$; or intravenous promethazine, $0.5 \mathrm{mg} \cdot \mathrm{kg}^{-1}$, plus intramuscular promethazine, $0.5 \mathrm{mg} \cdot \mathrm{kg}^{-1}$, to a total maximum of $25 \mathrm{mg}(n=50)$. Both treatments were administered in a double-blind fashion. Tracheal intubation was performed, without the use of muscle relaxants, under halothane (3.0-3.5 per cent inspired) in oxygen. Anaesthesia was maintained with halothane ( $1.25-1.5$ per cent inspired) in a mixture of nitrous oxide and oxygen $\left(\mathrm{FIO}_{2}=0.33\right.$ ) using mechanical ventilation. The tracheal tube was removed in the operating room, before the cough reflex returned.

In the post-anaesthesia recovery room (PARR), two trained nurses not aware of the treatment administered to each child recorded the recovery scores, ${ }^{13}$ the incidence of vomiting, the incidence of side effects, and the duration of stay in the PARR. Once the Steward recovery score reached the maximum of six, each child was transferred to the short-stay surgical unit (SSSU) where two trained nurses not aware of the treatment received by each child recorded the incidence of vomiting, the incidence of side-effects, and the duration of stay in the SSSU. Children were discharged from the hospital and carried home when they met three discharge criteria: (1) stable vital signs; (2) clear sensorium; and (3) absence of retching or vomiting during the last hour. Oral fluids were not offered if the child did not ask for them. Retching was included in the incidence of vomiting. Nausea was not evaluated. Side-effects investigated and recorded included the presence or absence of dry mouth, restlessness, disorientation, somnolence and miscellaneous (rash, urinary retention, cycloplegia, extrapiramidal symptoms, or others). Restlessness was defined as any state of agitation requiring loving care and/or acetaminophen.

Acetaminophen, $10 \mathrm{mg} \cdot \mathrm{kg}^{-1}$, per rectum, was administered to any child who seemed to experience pain after surgery. Narcotics were not administered at any time. Intramuscular dimenhydrinate, $1 \mathrm{mg} \cdot \mathrm{kg}^{-1}$, was prescribed to any child with two or more episodes of vomiting (and/or retching) per hour. 
TABLE I Demographic Data

\begin{tabular}{llll}
\hline & Droperidol & Promethazine & Statistical significance \\
\hline$n$ & 50 & 50 & NS \\
Sex (females/malks) & $(27 / 23)$ & $(30 / 20)$ & NS $\doteqdot$ \\
Age $(y r)$ & $4.6 \pm 2.3$ & $4.7 \pm 2.3$ & NS $\ddagger$ \\
Weight $(\mathrm{kg})$ & $18.6 \pm 5.8$ & $19.6 \pm 7.7$ & NS $\ddagger$ \\
Duration of anacsthesia $(\mathrm{min})$ & $55.6 \pm 14.8$ & $56.2 \pm 12.9$ & NS $\ddagger$ \\
Muscles repaired* & $2(1-4)$ & $2(1-4)$ & NS\$ \\
\hline
\end{tabular}

Mean $\pm \mathrm{SD} ;{ }^{*}$ median (range); NS = no significant difference; ‘chi-square analysis; ‡unpaired $\mathrm{t}$ test;

$\S$ Mann-Whitncy rank sum test (two-tailed).

TABLE II Post-anaesthesia times

\begin{tabular}{lccl}
\hline & Droperidol & Promethazine & $P$ value \\
\hline Time in PARR (min) & $50.2 \pm 9.6(35-75)$ & $64.2 \pm 18.7(40-120)$ & $P<0.01^{*}$ \\
Time in SSSU (min) & $149.6 \pm 59.4(70-375)$ & $139.1 \pm 45.9(65-310)$ & NS* $^{*}$ \\
Time to discharge (min) & $199.8 \pm 60.2(110-420)$ & $203.3 \pm 48.9(140-355)$ & NS* $^{*}$ \\
\hline
\end{tabular}

PARR = post-anaesthesia recovery room; SSSU $=$ short-stay surgical unit.

Mean $\pm S D$; numbers in parentheses indicate minimum-maximum values; *Mann-Whitney rank sum test (two(ailed).

The parents of each child were contacted $24 \mathrm{hr}$ after discharge from the hospital by a research assistant (RN) to determine the incidence of vomiting or retching and the incidence of side-effects after discharge. Both the parents and the research assistant were unaware of the treatment administered to each child.

Statistical significance $(P<0.05)$ was determined using Chi-square analysis, unpaired t test, Mann-Whitney rank sum test (two-tailed), and Wilcoxon signed-rank test (two-tailed) with the Bonferroni correction to make pairwise comparisons, where appropriate. Because the data were not normally distributed, the Mann-Whitney rank sum test (two-tailed) was used to determine differences between post-anaesthesia times.

\section{Results}

The number of children ( $n$ ), sex (females/males), the mean age and weight, duration of anaesthesia, and the number of extraocular muscles operated upon did not differ between the two treatment groups (Table I). Children treated with promethazine stayed longer in the PARR than children treated with droperidol, while time in the SSSU and time to discharge from the hospital (time in the PARR + time in the SSSU) did not differ significantly among the two treatment groups (Table II).

There was no vomiting or retching in the PARR. The incidence of vomiting predischarge (in the PARR + in the SSSU) was eight per cent with droperidol and two per cent with promethazine (NS). The incidence of vomiting postdischarge was higher with droperidol (54 per cent) than with promethazine (ten per cent). The overall incidence of vomiting was also higher with droperidol (56 per cent) than with promethazine (ten per cent) (Figure 1). One child in the promethazine group (two per cent) and three children in the droperidol group (six per cent) had one episode of vomiting in the SSSU followed by one to three episodes of vomiting during the postdischarge period (NS).

The incidence of vomiting after discharge, in children treated with droperidol (54 per cent), was significantly higher than the incidence of vomiting predischarge in this same treatment group (eight per cent) (Figure 2). In the group of children treated with promethazine, the incidence of vomiting postdischarge (ten per cent) was not different from the incidence of vomiting before discharge (two per cent) (NS).

Children treated with promethazine presented a higher incidence of restlessness ( 36 per cent) than children treated with droperidol (eight per cent) (Table III). This higher incidence of restlessness occurred principally in the PARR and was prevented or relieved by using rectal acetaminophen $\left(10 \mathrm{mg} \cdot \mathrm{kg}^{-1}\right)$ : each child who presented restlessness was calmed with acetaminophen; none of the children who received acetaminophen on the arrival at the PARR presented restlessness $(n=25)$. With the exception of restlessness, the overall incidence of side-effects was not statistically different between the two treatment groups (Table III).

None of the children included in this study required intramuscular dimenhydrinate. None of the children who 


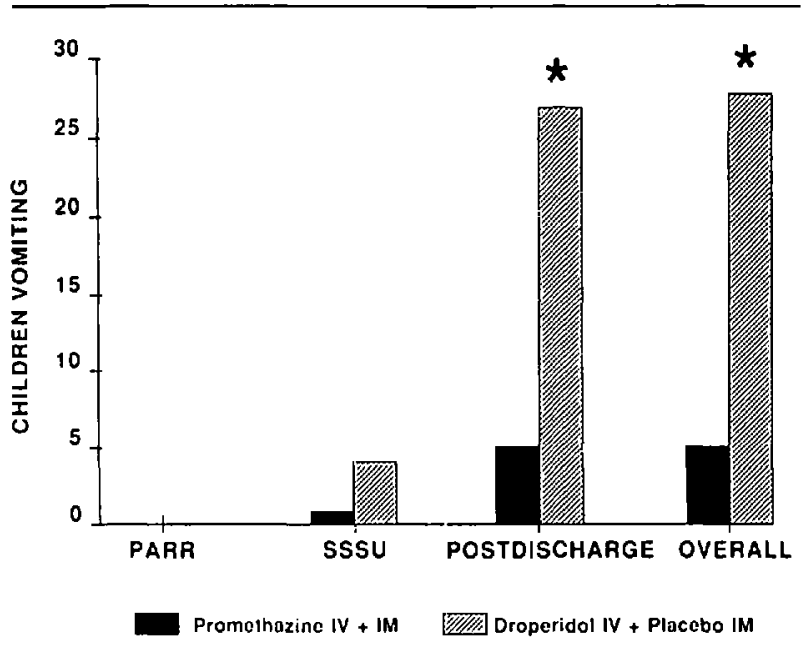

FIGURE I Incidences of postoperative vomiting in children undergoing outpatient strabismus surgery with promethazine IV + IM versus droperidol IV + placebo IM. PARR $=$ in the post-anaesthesia recovery room; SSSU $=$ in the short-stay surgical unit; ${ }^{*}=P<0.0001$.

vomited after discharge from the hospital required readmission for vomiting.

\section{Discussion}

Postoperative emesis is a complex problem. Several factors, related or not to anaesthesia, may influence the incidence of postoperative nausea, retching and vomiting. ${ }^{11,14}$

In the present study, the incidence of vomiting predischarge (vomiting and/or retching in the PARR + SSSU) was only eight per cent with droperidol and two per cent with promethazine. The incidence of vomiting postdischarge was less with promethazine (ten per cent) than with droperidol (54 per cent) (Figure 1). In the group of children pretreated with droperidol IV + placebo IM, there was a sudden increase in the incidence of postoperative vomiting when children were discharged from the SSSU and taken home (postdischarge period) (Figure 2). In contrast to droperidol IV + placebo IM, promethazine IV + IM maintained an incidence of vomiting postdis-

TABLE III The overall incidence of side effects $(\%)$

\begin{tabular}{lrcl}
\hline & Droperidol & Promerhazine & $\begin{array}{l}\text { Statistical } \\
\text { significance }\end{array}$ \\
\hline Dry mouth & 22 & 16 & SS* $^{*}$ \\
Restlessness & 8 & 36 & $P<0.001^{*}$ \\
Disorientation & 6 & 6 & NS* \\
Somnolence & 68 & 62 & NS* \\
Miscellaneous (rash) & 4 & 2 & NS* \\
\hline
\end{tabular}

Values in percentage (absolute value $=$ value $\% \times 50 / 100)$; MannWhitney rank sum test (two-tailed).

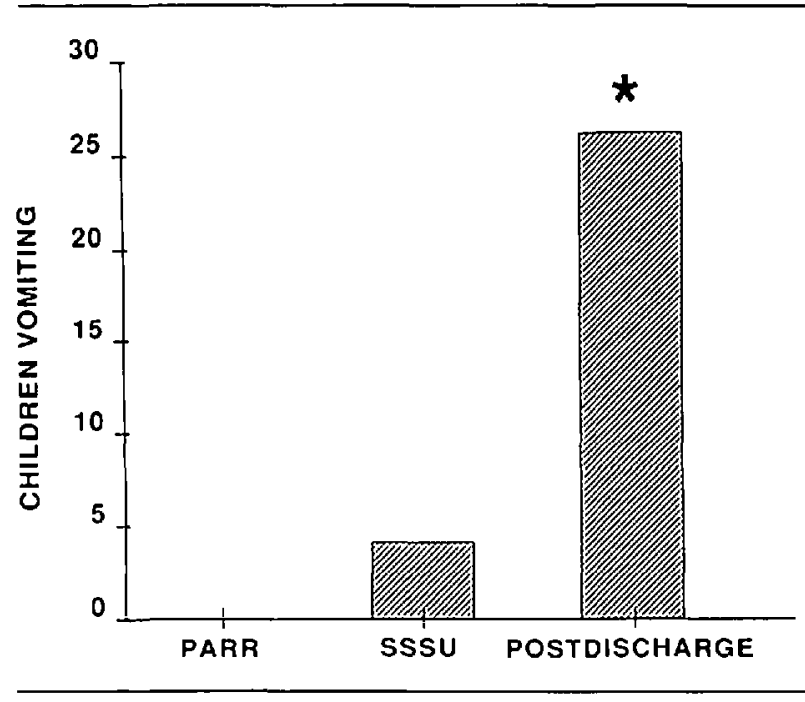

FIGURE 2 Postoperative incidences of vomiting in children pretreated with droperidol IV + placebo IM. PARR = in the postanaesthesia recovery room; SSSU $=$ in the short-stay surgical unit; $*=P<0.01$ when compared with the incidences of vomiting in the PARR and in the SSSU (Wilcoxon signed-rank test - two-tailed - with the Bonferroni correction for three comparisons).

charge and overall which was not higher than the incidence of vomiting in the PARR and/or in the SSSU. Thus, movement from the PARR to the SSSU, and from the SSSU to home, tends to increase the incidence of vomiting more easily after droperidol than after promethazine. In a previous study by Hardy et al.,$^{5}$ the incidence of postoperative emetic symptoms in patients given droperidol, was only six per cent in the PARR, but 42 per cent in the SSSU, and 56 per cent in the postdischarge period of Day 1.

The incidences of vomiting predischarge observed in this study were similar to that of the group pretreated with intravenous droperidol in the study by Lerman et al. ${ }^{6}$ (Table IV). But the incidence of vomiting postdischarge, in our group of children pretreated with droperidol IV + placebo IM (54 per cent) was higher. Two obvious differences existed between our protocol and that reported by Lerman et al. Firstly, in their study anaesthesia was induced with intravenous thiopentone, atropine $(0.02$ $\mathrm{mg} \cdot \mathrm{kg}^{-1}$ ) and succinylcholine, while in the present study anaesthesia was induced with halothane, nitrous oxide and oxygen by mask, followed by intravenous atropine $(0.01$ $\mathrm{mg} \cdot \mathrm{kg}^{-1}$ ), and tracheal intubation was performed, without the use of succinylcholine, under deep halothaneoxygen anaesthesia. Secondly, in the study by Lerman $e t$ al., discharge criteria were more strict than in the present study and, consequently, time for discharge from the hospital $(6.4 \pm 1.6 \mathrm{hr})$ was almost twice as long as that observed in the present study $(3.3 \pm 1 \mathrm{hr})$. Whether or not the type of anaesthesia influences the incidence of 
TABLE IV The incidence of vomiting predischarge according to the anticmetic used in children undergoing outpatient strabismus correction

\begin{tabular}{|c|c|c|}
\hline Antiemetic used (dose; time) & Incidence of vomiting & References. \\
\hline $\begin{array}{l}\text { Droperidol }\left(0.075 \mathrm{mg} \cdot \mathrm{kg}^{-1} \mathrm{IV} ; 30 \mathrm{~min} \text { before }\right. \\
\text { end of surgery) }\end{array}$ & $43 \%$ & Abramowitz ef al. ${ }^{2}$ \\
\hline Metoclopramide $\left(0.15 \mathrm{mg} \cdot \mathrm{kg}^{-1}\right.$ IV; in PARR) & $35 \%$ & Broadman es al. ${ }^{7}$ \\
\hline $\begin{array}{l}\text { Droperidol }\left(0.075 \mathrm{mg} \cdot \mathrm{kg}^{-1} \mathrm{IV} ; 10 \mathrm{~min} \text { before }\right. \\
\text { surgery) }\end{array}$ & $10 \%$ & Lerman et al. ${ }^{6}$ \\
\hline $\begin{array}{l}\text { Droperidol }\left(0.075 \mathrm{mg} \cdot \mathrm{kg}^{-1} \mathrm{IV} ; 10 \mathrm{~min} \text { before }\right. \\
\text { surgery) }\end{array}$ & $8 \%$ & Present study \\
\hline $\begin{array}{l}\text { Promethazine }\left(0.5 \mathrm{mg} \cdot \mathrm{kg}^{-1}+0.5 \mathrm{mg} \cdot \mathrm{kg}^{-1}\right. \\
\mathrm{IM} ; 10 \mathrm{~min} \text { before surgery) }\end{array}$ & $2 \%$ & Present study \\
\hline
\end{tabular}

vomiting, in children pretreated with intravenous droperidol $\left(0.075 \mathrm{mg} \cdot \mathrm{kg}^{-1}\right)$ and undergoing strabismus surgery, remains to be investigated. But it seems unlikely that the type of anaesthesia influences the incidence of vomiting postdischarge without influencing the incidence of vomiting predischarge. As far as time for discharge is concerned, it must be admitted that children pretreated with intravenous droperidol require a longer period of rest in the SSSU, if one wants to reach the low incidence of vomiting postdischarge reported by Lerman et al. (six per cent). ${ }^{6}$ However, the present study shows that children pretreated with promethazine IV + IM can be discharged from hospital after an average of three postoperative hours with a very low incidence of vomiting postdischarge and overall (ten per cent). If we wish to obtain an acceptable incidence of vomiting postdischarge ( $<$ ten per cent) therc are two choices: pretreatment with droperidol IV, and prolonged stay in the hospital or a brief stay with antiemetic protection by promethazine IV + IM.

Why is promethazine IV + IM more effective than droperidol IV + placebo IM against vomiting postdischarge in children staying no more than $3.3 \pm 1 \mathrm{hr}$ in the hospital and why is promethazine more prone to induce postoperative restlessness than droperidol? It is tempting to admit that promethazine IV + IM acts for longer than droperidol IV + placebo IM. Promethazine has been reported to have a much longer elimination half-life (9.73 $\pm 3.4 \mathrm{hr})^{15}$ than droperidol $(2.2 \mathrm{hr}),{ }^{16}$ and promethazine, due to a pKa of 9.1 , is very slowly absorbed from the IM injection site. ${ }^{17-18}$ However, several clinical reports claim that the antiemetic effect of intravenous droperidol, $0.005-0.07 \mathrm{mg} \cdot \mathrm{kg}^{-1}$, is as long as $24 \mathrm{hr},{ }^{11}$ whereas the duration of the antiemetic action of promethazine is considered to last from 6 to $12 \mathrm{hr} .{ }^{19-20}$ Promethazine has high affinity for histamine $\mathrm{H}_{1}$ and muscarinic cholinergic receptors and has some affinity for dopamine $D_{2}$-receptors. ${ }^{10-11}$ On the contrary, droperidol has dopamineantagonist, 5-hydroxytryptamine-antagonist, and alpha ${ }_{2}-$ agonist properties, with a very weak affinity for histamine
$\mathrm{H}_{1}$-receptors and, practically, no antimuscarinic activity. ${ }^{10-11.21-23}$ Consequently, the higher incidence of vomiting postdischarge, in the group of children treated with droperidol IV + placebo IM, may be attributed, in part, to the low antimuscarinic and antihistaminic effects of droperidol. As motion sickness seems to involve muscarinic cholinergic and histamine $\mathrm{H}_{\mathrm{I}}$-receptors, ${ }^{10}$ we suggest that the aetiology of vomiting following strabismus surgery comprises two different mechanisms. Vomiting in the PARR, during and following awakening, when the patient is undisturbed by motion, may be attributed to the surgical stimulation of the sensory receptors of the eye and, through them, to the stimulation of the dopamine $D_{2}$-receptors of the area prostrema. Vomiting after discharge is better explained as a form of motion sickness resulting from acute eye imbalance and diplopia (optokinetically induced motion sickness), ${ }^{8}$ rather than from direct labyrinthine stimulation, leading to stimulation of histamine $\mathrm{H}_{1}$ and muscarinic cholinergic receptors which activate the vestibular nuclei and the emetic centre. Indeed, it is known that there is a powerful convergence of information from the eye to the vestibular nuclei and, through the brainstem reticular formation, to the vomiting centre. ${ }^{24-25}$

As far as restlessness is concerned, it has been demonstrated that central muscarinic cholinergic receptors comprise two different populations: $\mathrm{M}_{1}$-receptors are more concentrated in the cortex and $\mathbf{M}_{\mathbf{2}}$-receptors are more abundant in the pons. Hyoscine and promethazine are effective anti-motion sickness agents producing a high incidence of restlessness because they are equipotent in both the cortex and pons. Thus, they probably cause restlessness because they are not highly selective $\mathrm{M}_{2-}$ antagonists. ${ }^{26}$ On the other hand, droperidol has no antimuscarinic activity and has been shown to enhance opioid analgesia. ${ }^{27}$ This last action seems to be due to its alpha $a_{2}$-agonist and dopamine-antagonist properties. Alpha ${ }_{2}$-agonists are effective analgesics and potentiate opioid-induced analgesia. ${ }^{28-31}$ Central and spinal de- 
scending dopaminergic pathways probably involved in pain modulation have been demonstrated. ${ }^{32-33}$

All these physiological and pharmacological data explain why promethazine may be more effective than droperidol in reducing the incidence of vomiting after discharge following strabismus surgery, and why droperidol pretreatment may enhance postoperative analgesia and contribute to a lower incidence of postoperative restlessness (eight per cent) than promethazine (36 per cent). Also, it seems easier to understand why the incidence of restlessness with promethazine pretreatment may be greatly reduced or prevented by reducing the incidence of postoperative pain with an analgesic-like rectal acetaminophen $\left(10 \mathrm{mg} \cdot \mathrm{kg}^{-1}\right)$.

The cost of treatment is also important. One phial of droperidol $(2 \mathrm{ml}=5 \mathrm{mg})$ costs $4.24 \$ \mathrm{Can}$. One phial of promethazine $(1 \mathrm{ml}=25 \mathrm{mg})$ costs 0.17 \$Can.

In conclusion, we have shown that promethazine pretreatment $\left(0.5 \mathrm{mg} \cdot \mathrm{kg}^{-1} \mathrm{IV}+0.5 \mathrm{mg} \cdot \mathrm{kg}^{-1} \mathrm{IM}\right)$ reduces the incidence of postoperative vomiting in unpremedicated children undergoing outpatient strabismus correction. Promethazine pretreatment permits reduction of the time for discharge from the hospital to three hours while keeping a low incidence of vomiting. In addition, pretreatment with promethazine is less expensive than with droperidol. Finally, promethazine pretreatment requires the use of an analgesic such as acetominophen to reduce the incidence of postoperative pain and restlessness. An ideal antiemetic and anti-motion sickness drug, without the untoward cffects of droperidol and promethazine, would be welcome.

\section{Acknowledgements}

We thank Mrs. Louise Lortie, Renée Deboer, Diane Roy, and the nurses of the operating room, post-anaesthesia recovery room and short-stay surgical unit, who devotedly assisted us. Also, we extend a note of appreciation to the anaesthesia and inhalotherapy staff for their cooperation.

\section{References}

I Powley MP, Brown TCK. Postoperative vomiting in children. Anacsth Intensive Care 1982; 22: 111-3.

2 Abramowitz MD, Oh TH, Epstein BS, Ruttimann UE, Friendly DS. The antiemetic effect of droperidol following outpatient strabismus surgery in children. Ancsthesiology 1983; 59: 579-83.

3 Iwamoto $K$, Schwartz $H$. Antiemetic effect of droperidol after ophthalmic surgery. Arch Ophthalmol 1978; 96: 1378-9.

4 Hadaway EG, Ingram RM. Traynar MJ. Day case surgery for strabismus in children. Trans Ophthalmol Soc UK 1977; 97: 23-5.

5 Hardy JF, Charest J, Girouard G, Lepage $Y$. Nausea and vomiting after strabismus surgery in preschool children. Can Anaesth Soc J 1986; 33: 57-62.

6 Lerman J, Eustis S, Smith DR. Effect of droperidol pretreatment on postanesthetic vomiting in children undergoing strabismus surgery. Anesthesiology 1986; 65: 322-5.

7 Broadman LM, Ceruzzi W, Patane PS, Hannallah RS, Ruttimann $U$, Friendly $D$. Metoclopramide reduces the incidence of vomiting following stracismus surgery in children. Anesthesiology 1990; 72: 245-8.

8 Warner LO, Rogers GL, Martino JD, Bremer DL, Beach $T B$. Intravenous lidocaine reduces the incidence of vomiting in children after surgery to correct strabismus. Anesthesiology 1988; 68: 618-21.

9 Christensen S, Farrow-Gillespie A, Lerman J. Incidence of emesis and postanesthetic recovery after strabismus surgery in children: a comparison of droperidol and lidocaine. Anesthesiology 1989; 70: 251-4.

10 Peroutka SJ, Snyder SH. Anticmetics: neurotransmitter receptor binding predicts therapeutic actions. Lancct 1982; 1: 658-9.

11 Palazzo MGA, Strunin L. Anaesthesia and emesis II: prevention and management. Can Anaesth Soc J 1984; 31: 407-15.

12 Ryan JF, Todres ID, Coté CJ, Goudsouzian NG. A Practice of Anacsthesia for lnfants and Children. Orlando; Grune \& Stratton, 1986.

13 Steward $D J$. A simplified scoring system for the postoperative recovery room. Can Anaseth Soc J 1975; 22 111-3.

14 Palazzo MGA, Suunin L. Anacsthesia and emesis 1: etiology. Can Anaesth Soc J 1984; 31: 178-87.

15 Scwinghammer TL, Juhl R, Dittert LW, Melethil SK, Kroboth FJ, Chung VS. Comparison of the bioavailability of oral, rectal and intramuscular promethazine. Biopharm Drug Dispos 1984; 5: 185-94.

16 Jørgensen A. Metabolism and pharmacokinetics of antipsychotic drugs. In: Bridges JW, Chasseaud LF (Eds.). Progress in Drug Metabolism. London and Philadelphia: Taylor \& Francis, 1986; 9,4: 111-74.

17 Katzung BG. Basic and Clinical Pharmacology. 2nd cd, Los Altos, California: Lange Medical Publications, 1984.

18 Speight TM. Avery's Drug Treatment; Principles and Practice of Clinical Pharmacology and Therapeutics. 3rd ed, Baltimore: Williams and Wilkins; 1987.

19 Wood $C D$. Antimotion sickness and antiemetic drugs. Drugs 1979; 17: 471-9

20 Barnhart LR. Physicians' Desk Reference. 44th cd, Oradell, NJ: Medical Economics Company Inc, 1990. 
21 Hyttel J, Arht J. Characterisation of binding of ${ }^{3} \mathrm{H}-\mathrm{SCH}$ 23390 to dopamine $D_{1}$-receptors. J Neural Transm 1987; 68: 171-89.

22 Leysen JE, Gommeren W. Drug-receptor dissociation time, a new tool for drug research. Drug Dev Res 1986; 8: 119-31.

23 Ison PJ, Preoutka SJ. Neurotransmitter receptor binding studies predict antimetic efficacy and side effects.

Cancer Treat Rep 1986; 70: 637-41.

24 Brandt T, Dichgans J, Wagner W. Drug effectiveness on experimental optokinetic and vestibular motion sickness. Aerospace Med 1974; 45: 1291-7.

25 Barnes JH. The physiology and pharmacology of emesis. Mol Aspect Med 1984; 7: 397-508.

26 McCarthy B, Peroutka SJ. Differentiation of muscarinic cholinergic receptor subtypes in human cortex and pons: implications for anti-motion sickness therapy. Aviat Space Environ Med 1988; 59: 63-6.

27 Bach V, Carl P. Ravlo O, Crawford M, Kruse L. Extradural droperidol potentiates extradural opioids. Br J Anaesth 1985; 57: 238.

28 Yash $T L$. Pharmacology of spinal adrenergic systems which modulate spinal nociceptive processing. Pharmacol Biochem Bchav 1985; 22: 845-58.

29 Glynn CJ, Jamous MA, Teddy PJ, Moore RA, Lloyd $J W$. Role of spinal noradrenergic system in transmission of pain in patients with spinal cord injury. Lancet 1986; 1: 1249-50.

30 Tamsen A, Gordh T. Epidural clonidine produces analgesia. Lancet $1984 ; 2: 231-2$.

31 Eisenach JC, Lysak SZ, Viscomi CM. Epidural clonidine analgesia following surgery: phase 1 . Anesthesiology 1989; 71: 640-6.

32 Hökfelt T, Phillipson O, Goldstein M. Evidence for a dopaminergic pathway descending from A11 cell group to the spinal cord. Acta Physiol Scand 1979; 107: 393.

33 Tulunay FC, Ischiro $Y$, Takemori EE. The effect of biogenic amine modifiers on morphine analgesia. Eur $J$ Pharmacol 1976; 35: 285-7. 